\title{
KNOWLEDGE MANAGEMENT FOR IMPROVING BUSINESS PROCESSES: AN ANALYSIS OF THE TRANSPORT MANAGEMENT PROCESS FOR INDIVISIBLE EXCEPTIONAL CARGO
}

\author{
André Cristiano Silva Melo ${ }^{a}$ \\ Maria Aparecida Cavalcanti Netto ${ }^{b}$ \\ Virgílio José Martins Ferreira Filho * \\ Elton Fernandes ${ }^{a}$ \\ ${ }^{a}$ COPPE/Programa de Engenharia de Produção \\ ${ }^{\mathrm{b}} \mathrm{COPPE} /$ Programa de Engenharia Oceânica \\ Universidade Federal do Rio de Janeiro (UFRJ) \\ acsmelo@yahoo.com.br \\ aparecida@peno.coppe.ufrj.br \\ virgilio@ufrj.br \\ elton@pep.ufrj.br \\ * Corresponding author / autor para quem as correspondências devem ser encaminhadas \\ Recebido em 06/2009; aceito em 05/2010 após 2 revisões \\ Received June 2009; accepted May 2010 after two revisions
}

\begin{abstract}
This paper presents an organizational analysis methodology aimed at knowledge capitalization with a view to improving business processes. Based on a real problem in a large electric sector firm, this methodology is applied to managing the transport of indivisible exceptional cargo (IEC). In the firm in question, intellectual capital is a critical asset for service performance and is fundamental for achieving business excellence. Applied to the firm's transport management process, the approach proved appropriate to IEC transport-related organizational goals. A review highlights definitions and structures for improving business processes proposed previously in the literature. The results of applying the methodology are discussed at the end of the paper.
\end{abstract}

Keywords: knowledge management; business process management; indivisible exceptional cargoes; electric sector.

\section{Resumo}

Este artigo apresenta uma metodologia de análise organizacional que busca a capitalização do conhecimento, focada na melhoria dos processos de negócio. Baseado em um problema real de uma empresa do setor elétrico, essa metodologia é aplicada para o transporte de cargas excepcionais indivisíveis (CEI). Nessa empresa, o capital intelectual é um ativo crítico para o desempenho dos serviços e ele é fundamental para a excelência do negócio. A abordagem aplicada ao processo de gerenciamento do transporte de uma grande empresa brasileira de suprimento de energia elétrica mostrou-se adequada às metas organizacionais do transporte de CEI. Uma revisão destaca definições e estruturas para a melhoria dos processos de negócio previamente propostas na literatura. Os resultados da aplicação da metodologia são apresentados ao final do artigo.

Palavras-chave: gestão do conhecimento; gerência dos processos de negócio; cargas excepcionais indivisíveis; setor elétrico. 


\section{Introduction}

The dynamic nature of present-day markets requires that operations and supporting management systems are organized and structured in order to achieve satisfactory levels of efficiency, flexibility and service. Definite information associated with key points in the business processes has become a pre-requisite for monitoring the pursuit of operational excellence, attaining both internal and external client service goals and, consequently, securing return on investments. In this context, Business Process Management (BPM) is a basic condition for efficiency in the flows of material and information that permeate the firm and its logistics chain. The results produced by such management approaches include precise information on key steps in the businesses, identification of resources, simplification of procedures, reduction of conflicts among the parties involved and definition of performance criteria.

On the other hand, intensive use of Knowledge Management (KM) methodologies enables information to be identified, captured and capitalized as input for decision support tools. In this regard, intellectual capital is one of the main resources responsible for results in terms of flexibility, expressed as innovation and responsiveness to clients. The cost reductions (efficiency) and improved levels of service typical of competitive environments can also be achieved by means of KM-supported systems. In addition, business strategy development requires information on both internal factors (operational capacity, available capabilities, employee cooperation, management styles) and external ones (governmental policies, environmental issues, economic conditions). Obtaining such information includes handling and processing great volumes of data, which are necessary for aligning business goals and clients needs (Gunasekaran \& Nath, 1997).

Organizational analysis strategies supported by KM and directed to BPM are a master key to incorporating intellectual capital as a nodal resource in the pursuit of efficiency, flexibility and customer service. Even though the literature offers broad discussions of KM (Grundstein et al., 2003; Kalpic \& Bernus, 2002; Schulze, 2001; Stadelmann, 2000; Zack \& Serino, 1998; Nonaka \& Takeuchi, 1997; Rummler \& Brache, 1995) and BPM (Adesola \& Baines, 2005; Aguilar-Savén, 2004; Gulledge Jr. \& Sommer, 2002; Kalpic \& Bernus, 2002), there is still a scarcity of empirical research directed to discussing such managerial practices applied in specific and vital business environments, especially a lack of reports on countries as Brazil (Melo, 2006). Also, among the main reasons firms' work forces fail in implementing BPM strategies are the lack of understanding of the actual goals and expectations, and of the ability to implement the methodologies and the excessive number of currently existing methodologies.

This paper proposes a KM-supported and BPM-oriented organizational analysis methodology focused on steps towards capitalizing the knowledge necessary to improve processes connected with electric sector indivisible exceptional cargo (IEC) transport management in the Brazilian environment. Important contributions are identified based on a case study in a large Brazilian electric power firm, which is responsible for electric power generation and transmission in an area containing $51 \%$ of Brazil's households and accounting for $65 \%$ of GNP. This firm controls over $40 \%$ of power consumption in Brazil (Furnas, 2010). In such an environment, IEC transport management (IECTM) is required for replacement parts, reallocation of installed capacity or preventive equipment maintenance. In the vast majority of cases, IEC transport operations are costly and fundamental to minimizing risks of failure in power provision. Accordingly, IECTM is a critical issue in meeting efficiency and customer service goals in the electric sector. 
The paper is organized as follows. Firstly, a literature review on the main managerial themes (KM and BPM) spells out definitions and structures proposed previously in the literature. The organizational analysis methodology used to capitalize business process-related knowledge is presented below. The main results of applying this methodology to the IECTM process in a Brazilian electric power firm are highlighted and discussed.

\section{Literature Review}

\subsection{Initial definitions}

One of the most widely acknowledged contributions to managerial literature is Rummler \& Brache (1995). The authors analyze the firm's organization on the basis of a structure comprising nine variables obtained by cross-matching performance levels (organization, processes and activities) and performance needs (goals, design and management). The resulting cross-matched set comprises the drivers of the base-initiatives for organizational improvement. It is within this structure that tasks have to be performed so that firms reach their goals. Even when organized into traditional functional structures, firms aggregate business value through structures that cut across and integrate their functions, i.e., it is through their processes that firms promote alignment between goals and operations.

Harrington (1993) advocates process-oriented analysis because performance at that level offers both strategic advantages (systemic vision, ease of customer focus, innovation, flexibility etc.) and operational advantages (support to administration, structuring for new challenges etc.), which are typical of dynamic production systems).

Nonetheless, for the firm's workforces to operate efficiently, knowledge management must be promoted in relation to information on all performance levels in order to prevent the impact of local decisions generating distortions among processes and resulting in nonconformity with goals. Performance-enhancing initiatives must thus be supported by a knowledge base (goals, critical factors, obstacles, solutions and implications) that makes it possible to generate results organization wide. As a result, such initiatives will be able to promote awareness and motivation in all other related parts of the organization on the need for - and what is needed in order to bring about - change and innovation in their various procedures and processes.

Knowledge, understood as the structured accumulation of information, is fundamental to establishing specific capabilities that make it possible to develop solutions, decision-making, learning and teaching, enabling the organization to create, retain and assure value, and thus compete successfully in the long run (Nonaka \& Takeuchi, 1997; Stadelmann, 2000; Schulze, 2001). From an organizational point of view, human knowledge can be classified in two ways: (a) implicit or tacit knowledge, which is personal, context-specific and thus hard to formalize and communicate; and (b) explicit or codified knowledge, which is transmissible in systematic and formal language among individuals or groups (Zack \& Serino, 1998).

Business processes constitute a set of logically inter-linked activities directed to filling gaps between functional areas and adding value by means of procedures. Processes transform resources into products or services that must meet clients' expectations, so as to support the firm's goals and structure its value aggregation chain (Cruz, 2003; Rummler \& Brache, 1995; Davenport, 1994; Harrington, 1991). Accordingly, understanding processes is essential 
to business success, since processes are responsible for what will be offered. This is illustrated in Figure 1 (below) showing the possible relationship between knowledge and business processes from a strategic point of view (Villela, 2000; Johansson et al., 1993; Rummler \& Brache, 1995).

In Figure 1 business processes are linked to the goals through operational plans, targets and the strategic plan. Processes are modeled and designed only after the information generated by these business elements (internal knowledge) is available. Nonetheless, once operation starts, these processes must also be managed to capture market information (external knowledge), which is necessary for continuous improvement and adaptation to client needs. Thus, if well managed, business processes and knowledge produce a positive synergetic effect on the firm's performance.

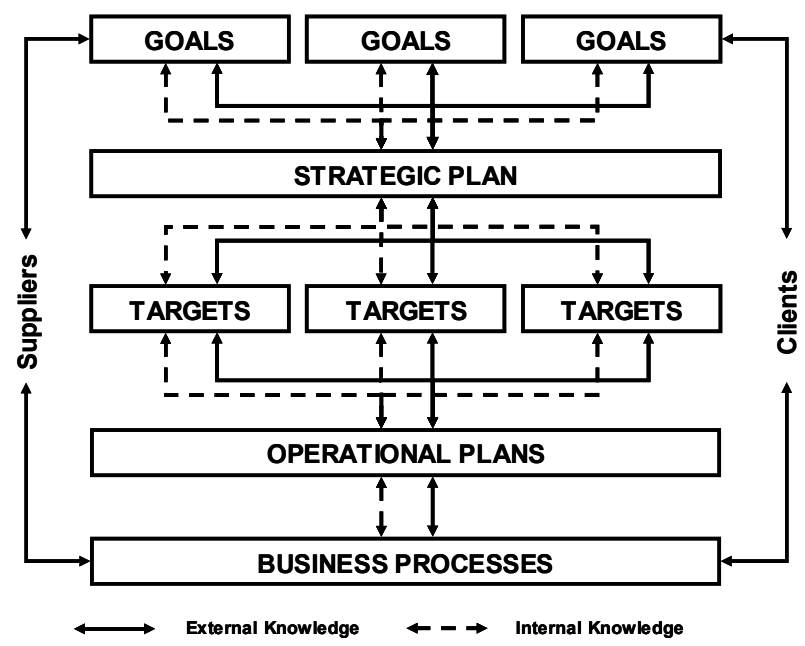

Figure 1 - Strategic view of business processes and knowledge.

Aguilar-Savén (2004) conducted a comprehensive review of business process modeling, describing the main techniques, as well as proposing and discussing a classification structure for these techniques, according to their purpose.

\subsection{Knowledge management}

Knowledge management (KM), a firmly established field of research, is directed to improving managerial actions designed to capitalize knowledge to enhance the firm's performance (creation, dissemination and utilization of knowledge) (Grundstein et al., 2003; Clarke \& Cooper, 2000; De Sordi, 2005). Several papers were identified addressing KM from an organizational point of view, involving: business processes (Jablonski et al., 2001; Roy et al., 2000; Stadelmann, 2000), collaborative practices (Clarke \& Cooper, 2000), knowledge reutilization (Yeung \& Holden, 2000), process and product-centered integration (Apostolou et al., 2000), use of knowledge discovery techniques integrated with decision support (Bolloju et al., 2002) and capitalization support methodologies (Barthelmé et al., 1998). In addition, the advance of information technologies has enabled major development 
in KM and support tools that foster externalization, diffusion, sharing and re-utilization of innovation-oriented knowledge (Schulze, 2001), computer-user interaction (Wang \& Ariguzo, 2004), development of digital information systems (Grundstein et al., 2003) and employee productivity and competence (Basu, 1998; Liao, 2003; Spiegler, 2003; Chua, 2004).

The main purpose of KM is to transform implicit knowledge into formalized (explicit) representations, clearly stated and simply managed, which render intellectual capital available for decision-making, development and innovation. Externalization is one of the most important steps in KM. However, it must be followed up by internalization (formal re-use of formalized knowledge), which has direct impact on process efficiency by making information available for re-use, closing the knowledge life cycle loop (Kalpic \& Bernus, 2002).

Nonaka \& Takeuchi (1997), considering human knowledge to be indivisible, proposed a dynamic model of knowledge generation that states clearly that knowledge conversion is a social process deriving from interaction among individuals, groups and organizations, rather than occurring inside each individual. On the supposition that knowledge "is created and expanded from social interactions between its basic forms (implicit and explicit)", these authors developed a model comprising four steps (socialization; externalization; combination; and internalization), characterized by interactions and conversions between such basic forms, constituting a cyclic process in which the steps can be repeated ad infinitum. This allows new and more valuable forms of knowledge to be created.

Based on Nonaka \& Takeuchi's model, Grundstein et al. (2003) developed a multi-faceted approach to the problem of capitalizing knowledge critical to decision-making and to essential processes for change and innovation. This approach introduces a digital information system view centered on a knowledge-worker platform. It is structured into the following steps: Location (necessary to organize and hierarchize knowledge); Preservation (acquisition, modeling, formalization and conservation of knowledge); Optimization (making knowledge accessible according to confidentiality and safety rules); Actualization (evaluation, standardization and valuing, which help capitalize external knowledge); and Management (promotes interaction among the previous steps necessary to capitalize knowledge). As the authors note, knowledge is a resource with the potential to leverage performance enhancement. In this regard, developing KM-supported organizational analysis strategies can help maintain and add value to intellectual capital by (re)building employee capabilities with a clear understanding of "what", "how", "who", "when" and "where" to execute each phase of operations, in addition to affording greater integration with partners and clients, as transactions become more transparent and efficient.

\subsection{Business process management}

Business process management (BPM) is a set of activities designed to assure that the organization's assets are in harmony, guaranteeing the efficiency of the operation, with input, transformation and output processes consuming only the resources necessary to attain the goals. BPM can be applied through radical changes (business process re-engineering, BPR) or gradual business process improvements (BPI) using approaches such as benchmarking and process redesign (Business Process Design - BPD) (Adesola \& Baines, 2005). It usually involves activities such as: documentation to understand process flows; property specification to establish responsibilities; management to optimize previously established performance measures; and improvement to increase product quality or process performance (Gulledge Jr. \& Sommer, 2002).

Pesquisa Operacional, v.30, n.2, p.305-330, Maio a Agosto de 2010 
BPM-oriented methodologies have developed greatly in recent years. Nevertheless, the number of implementation failures has been substantial (60\% to $80 \%$, according to Lockamy III \& Smith, 1997; and 50\% to 70\%, according to Hammer \& Champy apud Cameron \& Braiden, 2004). Chan \& Choi (1997) summarized these failures into two broader categories: (1) lack of understanding of the actual goals and expectations; and (2) lack of ability to implement the methodologies. Cameron \& Braiden (2004) stress one of the reasons for failure in BPI or BPR is the excessive number of methodologies proposed in recent years, which makes it difficult to select the one that best fits the firm's goals or those of specific projects directed to the meeting client needs effectively. In this connection, examples of specifically BPI-related methodologies are described and characterized in Franken et al. (1996), AL-Mashari \& Zairi (1999), Bhatt (2000), Bhatt \& Stump (2001), Gulledge Jr. \& Sommer (2002), Valiris \& Glykas (2004) and Adesola \& Baines (2005). BPR-related strategies and applications can be found in Macintosh (1997), Chan \& Choi (1997), Lockamy III \& Smith (1997), Gunasekaran \& Nath (1997), Khan (2000), Attaran (2003), Macintosh (2003), Cameron \& Braiden (2004) and Weicher et al. (2005).

Al-Mashari \& Zairi (1999) present an implementation script of a BPI program applied in an electric power firm. In this study, process enhancements were managed in four steps: preparation and start-up; current state assessment; future state design; and implementation. Adesola \& Baines (2005) developed a prototype MIPI (Model-based and Integrated Process Improvement) methodology, based on the analysis of several existing BPI structures, where four frameworks were selected and compared (Kettinger et al., 1997; Harrington, 1991; Smart et al., 1998; Klein, 1994). The resulting BPI prototype is developed in 7 steps: assess readiness; outline process under review; collect detailed data; form model of current processes; assess and redesign the processes; implement; and review processes.

According to Harbour (apud Khan, 2000), regardless of the BPM methodology adopted, there are nine basic principles to be considered: (i) eliminate and (ii) minimize waste, (iii) simplify whenever possible to (iv) combine processes, (v) design alternative steps, (vi) think in a parallel way, (vii) collect data at their sources, (viii) use technology for improvements and (ix) allow clients to help in the process. Performance improvement processes generally call for commitment and support from the firm organization's upper levels, besides careful attention to human factors and a gradual and systematic approach to implementation (AlMashari \& Zairi, 1999). In order to manage organizational performance well, variables must be directed to goals (strategy), assuring efficiency and alignment of processes with internal and external needs (Lockamy III \& Smith, 1997).

The diagram in Figure 2 below, from De Sordi (2005), shows that BPI and BPR methodologies both lead to changes (respectively, gradual and radical) in the organizational structure, which ceases to be based on business functions (the traditional management model), goes through a transition stage (function-process model) and, finally, becomes business process oriented (process management model).

However, as Adesola \& Baines (2005) remark, there is still room to expand the capacity of BPM methodology to produce gradual business processes improvement (BPI) by bringing them to focus on the practice of, and support for, implementation initiatives. 


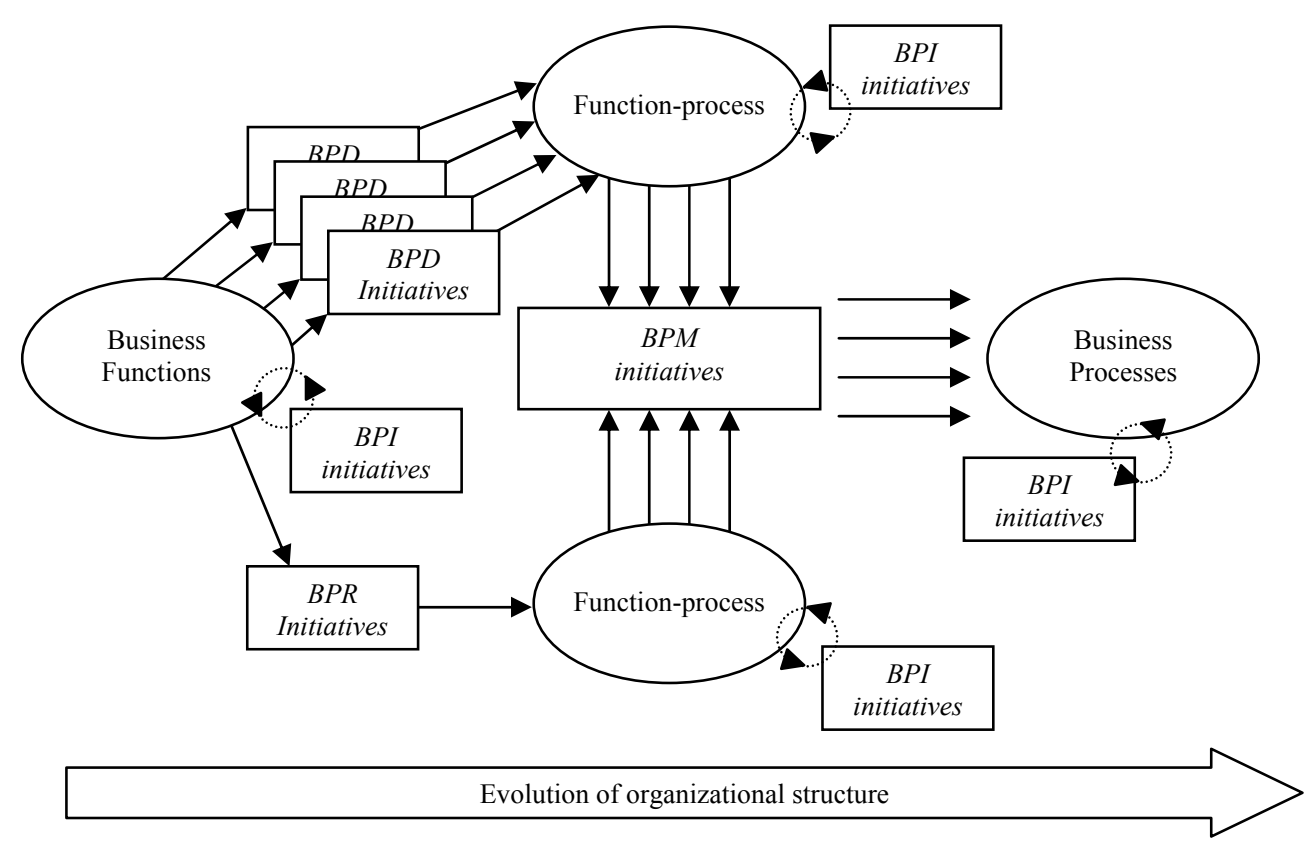

Figure 2-BPM strategies.

\subsection{Synergy between KM and BPM initiatives}

De Sordi (2005) highlights certain mutual benefits obtained from the synergic effect of applying BPM and KM approaches jointly to organization performance management. BPM methodologies offer support for the KM steps of: Socialization, by identifying instances (problems and opportunities) for subsequent analysis; Externalization, which helps build diagnostics of present process state (how it is), operating manuals and work instructions, in addition to facilitating collaborative work; Combination, during management of versions of operating processes in constant evolution (rules, activity flows, operators and technologies); and Internalization, by identifying changes, exceptions and bottlenecks and performing simulations in order to define critical paths (reactive functionalities).

Prominent potential benefits for BPM from KM include: (a) creation of provisions for continuous and systematic process improvement based on knowledge capitalization strategies; (b) spread of a culture of organizational innovation and change (flexibility), by creating communication channels and defining related technology, which enable information to be exchanged among areas of the firm involved and between them and the market (suppliers, partners, stakeholders and customers); and (c) identification of new market opportunities, by defining communication with customers and provisions for evaluating performance of the services offered.

Jablonski et al. (2001) highlight the following benefits expected by firms that organize KM-oriented organizational development programs: (a) transfer, availability, retention and reuse of know-how; (b) increased productivity by resource optimization and cost reductions; (c) increased competitiveness by improved internal processes, innovation skills, product 
quality and customer support; (d) promotion of internal communication by accessing new areas of knowledge, training inter-functional groups, and reinforcing core competences and creativity; and (e) reduction of project execution timeframes and financial transfers.

\section{The proposed organizational analysis methodology}

Most of the literature reviewed mentions the use of knowledge generation mechanisms as a condition for implementing managerial methodologies seeking improved process performance. However, there is a lack of reports setting out explicitly detailed procedures for identifying, locating and capturing the information necessary to accomplish the initial steps in such implementations, which influence performance of the most critical processes in practice. The organization analysis methodology proposed here is based on integrating a KM model into a BPM-oriented analysis approach. The aim of this methodology is to capitalize knowledge relating to Business Process Improvement (BPI), directing structure enhancements based on and guided by information from all firm performance levels. A descriptive diagram is shown in Figure 3 below. As in Figure 3, the methodology integrates an external cycle with an internal cycle for knowledge generation according to Nonaka and Takeuchi's model. The internal cycle comprises the steps of: socialization, through meetings and informal talks among consultants and employees in charge of the service; externalization, in which employees' tacit knowledge is formalized; combination, in which the knowledge formalized in the previous step is capitalized by association with other forms of knowledge already consolidated in the literature (re-engineering, process analysis and modeling etc.); and internalization, which represents the diffusion of the capitalized knowledge in the form of redesign of processes, procedures, instructions, rules, documents, strategies for the use of new technologies, and so on.

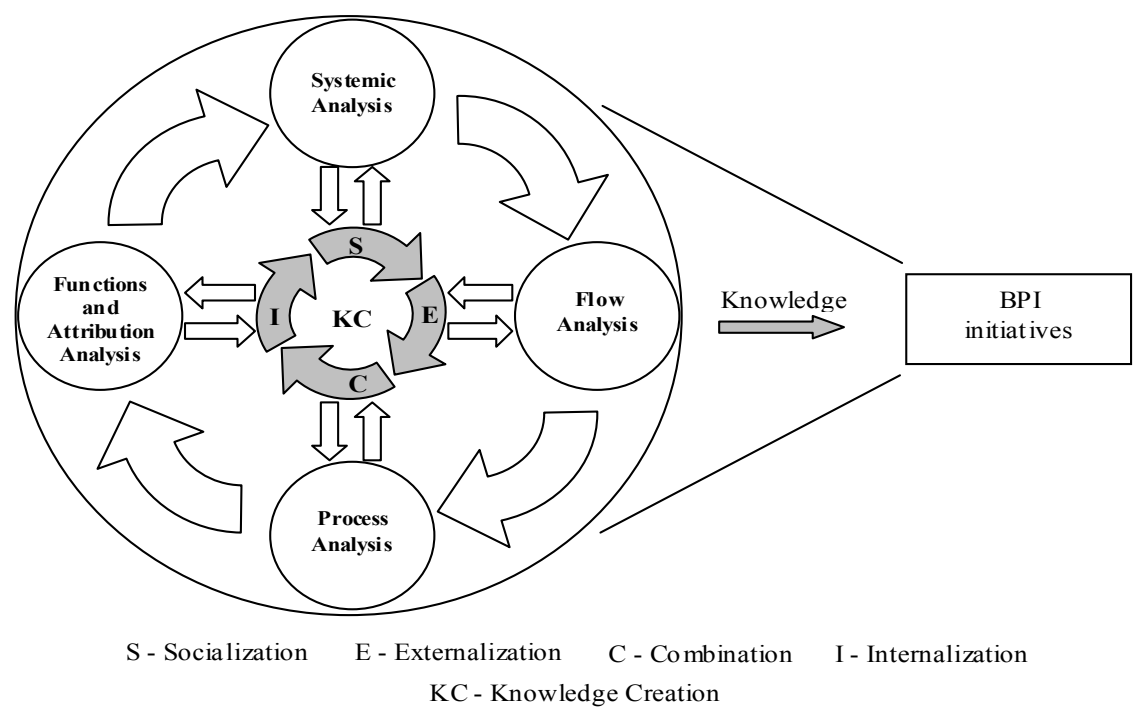

Figure 3 - Knowledge generation cycles for BPI initiatives. 
The external cycle constitutes an analysis script of organizational performance levels that had to be associated with the basic steps of knowledge creation in the KM model. The aim is to enable learning and, at the same time, to promote continuous enhancement of processes. With a view to comprehending better the firm performance levels, the script was based on the approach proposed by Rummler \& Brache (1995) and defines four major stages for analysis. The first (systemic analysis) refers to firm-level organizational performance; the second (flow analysis) extends to all performance levels; and the last two (process analysis and functions and attribution analysis) relate to the process and activity levels.

In fact, the internal cycle of the knowledge generation model corresponds to a spiral social process in which steps can be repeated indefinitely, enabling new and more valuable forms of knowledge to be created. Figure 4 shows the basic structure of this process (Nonaka \& Takeuchi, 1997; Nonaka \& Konno apud De Sordi, 2005). As can be seen from Figure 4, the Socialization step is executed by participants' sharing and exchanging experience (tacit knowledge) with a view to creating mental models and common skills (tacit knowledge) acquired by observation, imitation and practice, the key factor in this step being the participants' experience. Note that the Socialization step is always internal to the firm, and initially internal to the portion of its organization responsible for the service. The Externalization situation is induced by the participants' dialoguing and thinking together, so as to articulate their tacit knowledge, here transformed into models, figures and other more structured forms of knowledge, i.e., explicit knowledge. In this step, the knowledge developed, now explicit, can now be disseminated to other parts of the organization. The Combination step involves systematizing concepts within a knowledge system, where the connection and exchange among different areas of knowledge are achieved through documents, meetings, telephone calls or computer networks (Intranet and/or Internet). The underlying principle is that the new combination of existing information and the classification of explicit knowledge can add value to the knowledge. During this step, the (explicit) knowledge generated is analyzed from other standpoints external to both the portion of the organization responsible for the service and to the firm itself, and can be associated with existing complementary and convergent approaches (explicit knowledge). In this way, the knowledge will become of greater value (capitalized) to the firm. The Internalization step entails incorporating the - explicit and capitalized - knowledge, which is now absorbed by all those directly and indirectly involved, thus appropriated by each participant (tacit) and with added value greater than the sum of the information exchanged at the outset of the process. This step is performed by holding encounters (talks, forums and workshops) to discuss the subject and to develop documentation (articles, service specifications, work instructions) so as to circulate the results.

As in Figure 4, it is possible that many internal knowledge generation cycles (S-E-C-I) may occur at each stage of the analytical script of organizational performance levels (external cycle), in order to capitalize the necessary knowledge critical to performance enhancement and adaptation to current situations. The cyclical nature of this organizational analysis methodology permits decisions to be taken at each performance level analyzed, which consider the impacts on other performance levels. Such considerations help maintain the necessary dynamism and flexibility for fast responses to any market situation.

Below, the stages of the methodology are described in detail and additional implementation requirements are presented.

Pesquisa Operacional, v.30, n.2, p.305-330, Maio a Agosto de 2010 


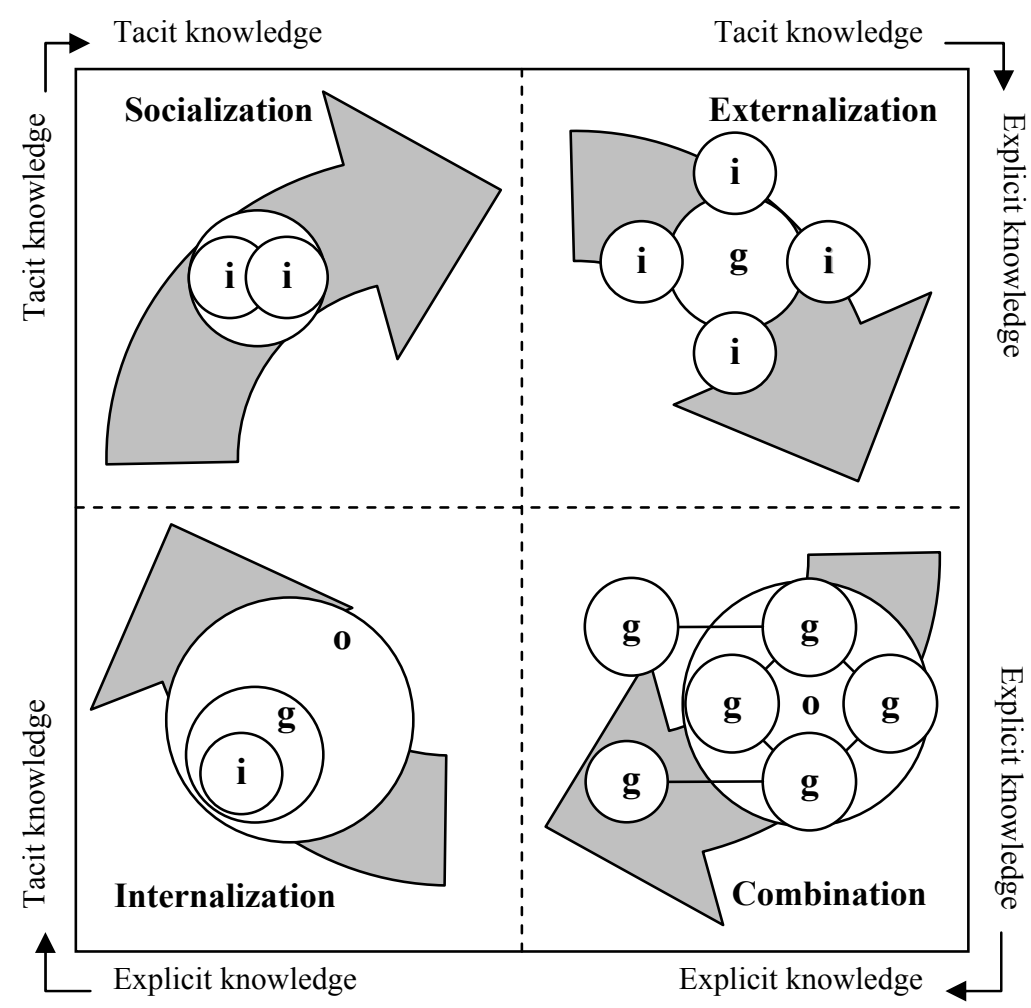

(i) Individuals (g) Group (o) Organization

Figure 4 - The knowledge generation spiral.

\subsection{Stages of the methodology}

\subsubsection{Systemic analysis}

The systemic analysis yields a view of the sector's production chain. The service's overall composition and its importance for defining business needs and related requests are considered, and the main agents (regulators, suppliers, partners and clients) and their relationship in performing the service are identified. This stage seeks a broader view of the potential variables considered in the overall characterization of the service.

The staff directly involved in this stage are those entitled to deal with management issues and relations with (internal and external) suppliers and clients. However, operational level staff, together with outside consultants and researchers, may also be present and form part of the group, or the work team.

During Socialization of the knowledge all staff involved should exchange information relating to how the service is structured overall. In many cases professionals external or internal to the organization analyzed are interviewed when they are directly or indirectly 
involved in performing the service. Systemic analysis is directed more to macro aspects and inquiries. The overall description of the service from the standpoint of each area involved, considering aspects deriving from activities that take place before (planning, scheduling, hiring etc.), during (service evaluation) and after (billing, payment) service execution, constitutes a starting point for identifying overall and specific features associated with meeting the various types of request.

Externalization starts when the information about service execution derived from interviews and exchanged among participants is structured and formalized. From the diagnostic reports on the present state of the firm's organization (how it is), an overall description of the service is presented, identifying demands, suppliers, customers and stakeholders, as well as each one's role in performing the service. In Combination, the formalized information (diagnostic reports on the present state) is analyzed against a wide-ranging review of the available literature (in virtual or other libraries, sector-specific websites etc.), considering strategies, techniques, quality standards and models developed by research and development institutions or disseminated as market best practices. It is also possible to consider activities relating to compliance with current legislation and, consequently, all the stakeholders involved (regulatory agencies, police etc.). All these items should be contemplated in drafting reports with proposals for service execution strategies more suited to the organization (how it should be). Internalization, at both this and other stages, entails pursuing spread strategies (presentations, talks, reports on results etc.) designed to equip those involved to make new analyses and obtain answers to questions relating to the performance level in question (chain and organization).

The main results expected relate to identifying the constituent steps in the service, the business demands or needs, the types of service requests, the business entities involved and the possible relations among these various sets of information.

\subsubsection{Flow analysis}

Based on the flow analysis stage, the resources necessary for the service to be performed fully are identified (material, equipment, services and information). This stage helps identify the logistic network, the order cycle, the information systems, technological needs and the possible interfaces between resources required to accomplish the service. It is through the internal and external flows, to or from the market, that the main business relationships can be identified and, through them, the business processes involved.

Staff at the managerial and operational levels participate in this stage. However, consultants, researchers and experts in flows and information systems should already be taking part, at the Socialization step, in identifying flows (information, documents, activities, inputs etc.) that enable the service to be performed. At this stage, one good strategy suggestion is to analyze the order cycle for the service from the participants' various different standpoints. From Externalization, consultants and researchers provide structured forms (reports) of the information exchanged and the knowledge developed on the information types and flows, as well as the relationships necessary to perform each step of the service offered by the organization to its present standards (diagnosis of the present state: how it is). That information can then be associated (Combination) with flow techniques and models (literature), documents from other areas, related legislation, rules internal and external to the organization etc. In this way, models of more efficient relationships for performing the service (how it should be) can be proposed, also in reports. Internalization can be performed

Pesquisa Operacional, v.30, n.2, p.305-330, Maio a Agosto de 2010 
by formulating and circulating or presenting reports to the areas of the organization directly and indirectly involved.

The results obtained on completion of this stage relate to identifying the types of information exchanged and the main service variables at each step of execution. The possible inter- and intra-business relationships are also defined (network of relationships), in terms of service request types.

\subsubsection{Business process analysis}

In business processes analysis, the service is seen as a sequence of activities and events with a common goal: fulfilling the request in conditions appropriate to the client's needs. In this regard, it is important to define a base structure (macro-process) able to assess the dependency relationships among sub-processes, identifying sequences of events, basic interfaces and critical paths. In this connection, what has to be defined are all the activities necessary to perform each sub-process, as well as the main types of flow (information, authorizations, requisitions, documents etc.) exchanged both among these activities and between them and other external activities (other areas of the organization or other business entity).

Participation by personnel (specialists) directly involved in performing the service (operations level staff), along with expert outside business process consultants and researchers, is fundamental at this stage. Related managerial level staff and other specialists (other areas of the firm) should also be present during this stage.

Socialization of knowledge should involve participation by at least one specialist in each component process of the service. These personnel should be able to enlighten the other participants as regards details (clients, suppliers, goals, inputs, tools and techniques, outputs) that demonstrate the importance of each process in performing the service. Other actions to be taken at this step are a process documentation review (service requests, service specifications etc.) and interviews of specialists in each process. After this clarification, the topics judged to be critical to the process are organized and formalized (Externalization) in diagnostic reports (how it is), which should then be associated (Combination) with process techniques and models (theoretical or practical) available in the specialized literature, in service specifications and in internal rules. The knowledge capitalized on the basis of that combination should be formalized in new reports (how it should be) and then re-evaluated by the specialists and other participants involved (outside consultants and researchers etc.).

Also during Combination possible scenario analyses are carried out so as to ensure that the macro-process developed is coherent with, and adheres to, the service goals. This scenario analysis itself can also be considered a form of knowledge internalization. All the material produced thus far (reports) can be made available (articles, talks, debates etc.) and internalized by the other participants in the work team.

On completion of this stage, the results obtained should constitute a structured macro-process with all the activities that make up the process and that fulfill whatever service requests are possible. Another result is the awareness built up among the specialists and other personnel of the organization as to each participant's importance and contribution to carrying out the service fully (efficacy) and to a suitable level of performance (efficiency). 


\subsubsection{Analysis of functions and attributions}

Analysis of functions and attributions helps identify and allocate the resources necessary to perform the service. It makes it possible to establish the value of each resource involved (people, material, equipment, capabilities, knowledge etc.) and the moment it is utilized. In this stage, the knowledge is generated and capitalized in a more evident manner: once the tacit knowledge (Know-why, Know-how, Know-how much, Know-when, Know-who, Know-where etc.) has been identified, located, captured, socialized and externalized, it will be matched to other forms of knowledge and later internalized by the participants through conferences, discussions, process maps, service specifications and work instructions.

Once again this stage will involve operational level personnel directly, supported by area managers, specialists from other areas of the firm (e.g. organization and methods, information systems etc.) and outside consultants and researchers.

A review of the documentation relating to the activity (job instructions, authorizations, contracts, invoices etc.), as well as interviews and information exchange (Socialization) among the employees directly involved in the process (operational level), are conducted in order to locate, identify and capture tacit information on details of the processes (activities, procedures and tasks) directly related to the service. This knowledge is then formalized (Externalization) in diagnostic reports on the present state of the service (how it is), which are then combined with other forms of knowledge (formalized) arising from area documentation, specialists from other areas and/or outside consultants and researchers. Also during Combination, reports are drafted that define the process structure most suited to the firm (how it should be). Once again, Internalization by the participants can be achieved through talks, simulations, discussions and by circulating process diagrams, service specifications and work instructions.

The results from this stage thus relate to drafting or redrafting of documents containing the information (Why, How, Who, When and Where) about goals, procedures, tasks and responsibilities that allows each activity to be learned and executed to the standards of quality and efficiency required in performing each process. In addition, these documents should contain flow diagrams defining the start and finish of each activity, as well as its tasks, interfaces with other activities (internal and external), inputs (resources and supplies), outputs (products and services) and control points used to evaluate service performance.

\subsection{Additional requirements for successful implementation of the methodology}

Additional requirements for successful implementation of the methodology include particularly:

(a) Commitment by the firm's senior management - making clear the need to foster performance improvements as a means to obtain competitive advantage or even for business survival - is a key factor for success in implementing the stages of the methodology; (b) for each area involved, a representative should be selected and tasked with motivating and orienting all the employees possibly related to the service in question as to the importance of complying with the specific requirements of the methodology. Some of these representatives should also be able to interface with related areas of knowledge. Such staff should have a more comprehensive understanding so as to be able to act impartially in relation to their areas, exclusively with a view to achieving best performance in executing the service; and (c) indirect participation by professionals from other decision levels, other areas of the organization and even outside consultants and researchers will enlighten the participants as to all possible deficiencies and weaknesses relating to the service.

Pesquisa Operacional, v.30, n.2, p.305-330, Maio a Agosto de 2010 


\section{Application to indivisible exceptional cargo transport management (IECTM) in a large Brazilian electric sector firm}

The methodology described in section 3 was applied to an indivisible exceptional cargo transport management (IECTM) problem in a large firm in the Brazilian electric power sector (Furnas Centrais Elétricas S.A.). The main issues as regards the information resulting from application of the methodology are presented in the sub-sections below. SCEI-cycles were conducted intensively during application so as to have all the main IECTM-related processes and sub-processes clearly understood, mapped and redesigned. The information detailed, located, captured and capitalized, as well as the stages relating to the cyclic knowledge generation process, can be examined in Melo (2006).

\subsection{IEC transport management}

Indivisible exceptional cargo (IEC) comprises any cargo in a single structural piece or set of fixed pieces, which is subject to strict transport regulations due to its large dimensions. The dimensions and/or weight of such cargo are generally subject to quite restrictive legislation (Schoeler, 2000; DNIT, 2004). Examples of IEC are large fuel and liquefied gas reservoirs or, in the electric sector, power transformers and electrical reactors, and so on. In general, IEC availability is of strategic importance, because it is an efficient manner of ensuring production system stability and reliability. The high aggregate value of such parts makes stocking strategies unworkable. The need for regular maintenance requires moving IECs physically, not only in order to maintain them in fully working condition, but also to maintain flexible production capacity in the installations that use them. Thus, such cargo becomes essential to keeping certain industrial processes effective and efficient.

Increasing industrial expansion in Brazil has boosted the frequency of IEC transport. Between 1997 and 2001, 3,604 transport authorizations were issued for this kind of cargo (DNIT, 2003). The basic characteristics that orient decisions on this service are the large volumes and/or weights, the indivisibility of the cargo and the long distances involved.

In the electric power sector, for example, efficient transport of power transformers is crucial, because it brings flexibility to sub-station transmission capacity. Flexibility is necessary in order to respond to energy demand, which shifts in place and time through the various different regions. It is one of the parameters associated with low risk of failure in power provision and with maintaining satisfactory service levels.

In the Brazilian electric power firm case study, IEC transport is performed essentially by road and scheduling is thus sensitive to variations in road conditions. Accordingly, when compared with other freight categories, IEC transport involves high levels of uncertainty and, therefore, high risk of non-finalization or inefficient completion. Such risk translates into non-fulfillment of production plans (service level), large fines (costs) for nonperformance of contract targets, and dissatisfied clients. In this sense, IECTM is extremely important for preventing problems which, even without major direct consequences to the cargo, can entail the risk of transport delays and thence impacts in production (failure due to lack of production capacity) and costs (wastes and fines) in various industrial sectors.

IEC transport constraints include route-related physical limitations, specific legislation, need for operational infrastructure and multiple business relations with a small number of suppliers which very often behave monopolistically. These restrictions call for analysis of a 
number of technical and institutional aspects, since this kind of transport is very closely regulated. Best performance in IEC transport entails using special transport equipment and decision tools which consider a complex combination of variables (cargo origin- and destination-related variables), resulting in a detailed schedule of activities.

As indicated in general terms by Melo et al. (2005), the IEC transport order cycle is initiated when, in response to a business demand or need on the part of an IEC user, an internal client (requesting area) defines the type of transport request to be forwarded to the area responsible for managing the service (internal supplier). On receipt of the request, the internal supplier (transport management area) interacts with the related areas, including the internal client, and exchanges information necessary to support decision making. At the outset, detailed scenario analysis contemplating the main perceived variables (origin/destination, type of IEC to be moved and costs involved) can help decisions such as: selection of transport mode and equipment or alternative routings. In the case of IEC procurement, in addition to such decisions, this analysis will also help define the transport specifications (weight, width, height etc.). Regardless of the type of request, this first phase of service planning (internal planning) should estimate technical and operational specifications, as well as service costs, with support from knowledge areas judged to be directly involved in the IEC life cycle. Such support is obtained by socialization and combination of technical information specific to the related areas and from joint analyses of the physical, operational and economic constraints on the service. This first phase aims to establish the product(s) (goods and services) necessary to fulfill the request.

In the second planning phase (external planning), inter-business integration is established by exchanging technical information among the user, carriers, IEC suppliers and other entities in such a way that a set of services involved in the transport is defined technically, operationally and economically. Once the possible products to be procured have been defined, processes (procurement and/or hiring) are initiated within the IEC user with a view to selecting the most suitable suppliers, according to the goal of fulfilling the request. Once such processes have been initiated, the exchange of commercial information defines the best choice among the possible suppliers available on the market. Following selection of the supplier(s), only the business entities directly involved exchange the administrative information necessary to coordinate between the transport and other activities (issue of authorizations, route clearance, and so on) which may influence performance.

Figure 5 shows, in general terms, some of the documents relating to the IEC transport order cycle.

At the various steps of the service, control points have to be defined. These are necessary to evaluate performance of the operation. At such points, information is collected (events, route, cargo behavior, irregularities, and so on) which will feed a historical operations data base. The information collected can be evaluated both against parameters defined during service planning (predictive information) and against information from previous services (operations data base). The capture and evaluation of this information constitutes feedback to the transport management system, which ensures continuous, systematic improvement by reducing errors and risks in the operation. 


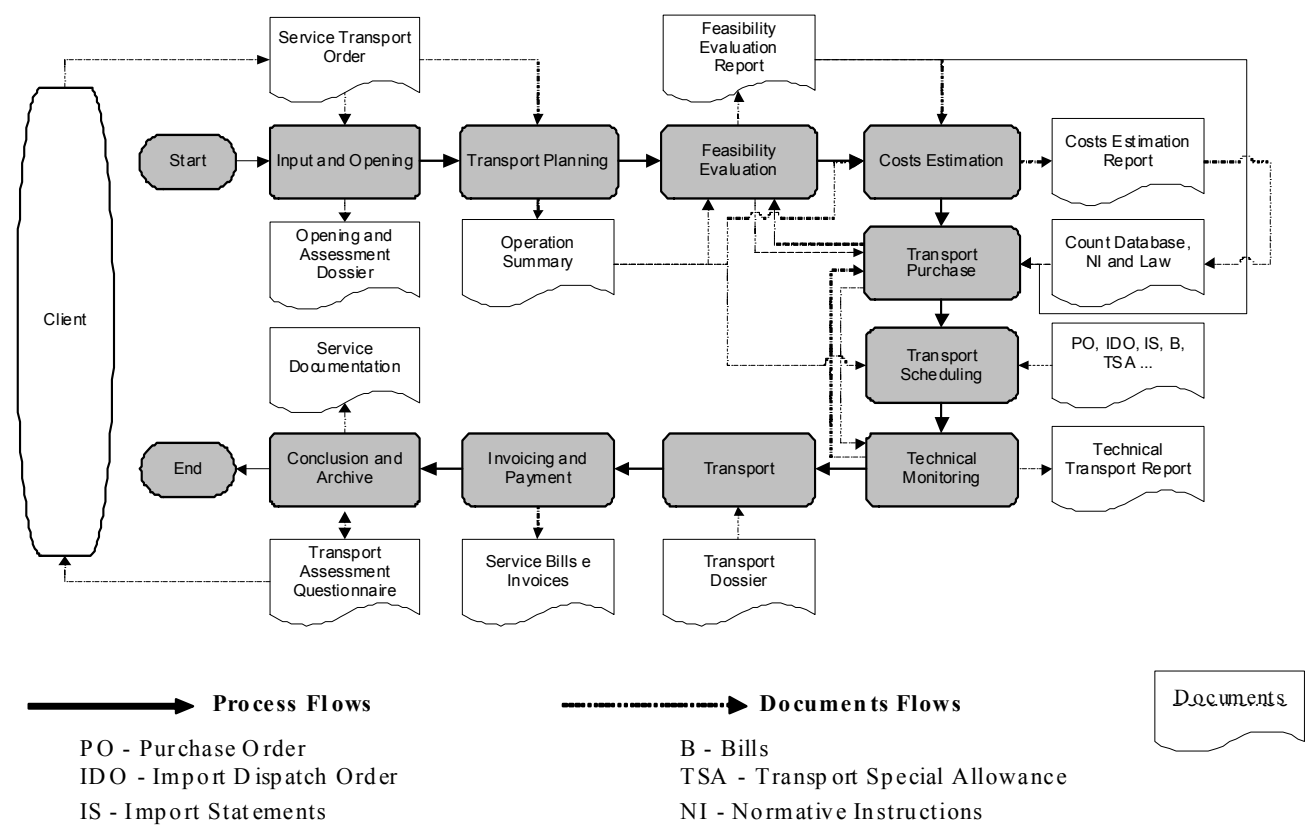

Figure 5 - IEC transport order cycle.

\subsection{Main issues resulting from case application}

\subsubsection{Systemic analysis}

Systemic analysis of IEC transport in the electric sector has yielded fundamental information for developing a broader strategic view of the operation, making it possible to define and characterize in detail the service steps, business needs, types of request and organizations involved. Chart 1 (below) summarizes the main information in this stage of analysis.

Chart 1 - Information obtained during systemic analysis of IEC transport.

\begin{tabular}{|c|c|c|c|}
\hline Service Steps & Business Needs & Types of Request & Organizations Involved \\
\hline $\begin{array}{l}\text { - Transport } \\
\text { Planning } \\
\text { - Transport } \\
\text { Scheduling } \\
\text { - Transport } \\
\text { Execution } \\
\text { - Transport } \\
\text { Performance } \\
\text { Evaluation }\end{array}$ & $\begin{array}{l}\text { - Production } \\
\text { capacity } \\
\text { enlargement } \\
\text { - Production } \\
\text { capacity } \\
\text { maintenance } \\
\text { - Installation lay-out } \\
\text { changes }\end{array}$ & $\begin{array}{l}\text { - Purchase } \\
\text { - National } \\
\text { - International } \\
\text { - Repair } \\
\text { - In warranty } \\
\text { - Out of warranty } \\
\text { - Transfer } \\
\text { - Removal }\end{array}$ & $\begin{array}{l}\text { - IEC Suppliers } \\
\text { - IEC Users } \\
\text { - Engineering } \\
\text { - Operations } \\
\text { - Procurement } \\
\text { - Contracting } \\
\text { - Finance } \\
\text { - Transport } \\
\text { management } \\
\text { - IEC Carriers } \\
\text { - Infrastructure entities } \\
\text { - Other organizations }\end{array}$ \\
\hline
\end{tabular}




\subsubsection{Analysis of flows involved in service execution}

Flow analysis of IEC transport order processing has enabled a specific logistics model to be developed for the electric sector. In this model, information, services and materials flows are represented by two distinct logistic sub-systems: a main subsystem and a supportive subsystem. The main logistic subsystem is directed to the main business goals, and considers physical flows and sector-specific logistic activities. This subsystem refers to decisions about the location of installations (plants and sub-stations), description of transmission and distribution networks (lines and towers), and electric power transport carried out by equipment sets (transformers and distribution and transmission lines) which assure power supply is available at economically viable levels at consumption sites (clients). Since electricity cannot be stored as a finished product, it is kept in primary state until transformed into electric power which is pulled by actual demand. This demand serves as a parameter for infrastructure optimization plans for electric sector macro-functions (power generation, transmission and distribution). In this sector, the expansion and maintenance of productive capacity at different times and locations define the service level represented by the risk of interruption in power provision.

The supporting logistic sub-system is as important as the main one. It comprises decisions, flows and activities that aim to maintain operational efficiency and stability in the sector. In this subsystem, transport is generally carried out by suppliers responsible for transferring materials to the respective installations (warehouses, plants and sub-stations). Depending on the value or type of material, regularity of demand and re-supply times, material stock levels can be kept high or low and, in turn, can be pushed (decentralized) or pulled (centralized). The main concerns are the location and capacity of suppliers' installations and distribution centers, since the network must provide the best level of service, represented by electric material and adequate services being available where and when needed. This subsystem constitutes the portion of the logistic system that assures that materials, components, and electric equipment are available to the installations of the main subsystem, in such a way as to assure that electric power flows continuously and the system is reliable and stable.

From the types of request, a number of different relationships were also identified, both among business units internal to the firm considered in this study, and between these and other external entities (government, clients and suppliers) involved in the service.

\subsubsection{Process analysis}

Business process analysis of IECTM yielded a conception of macro-process in this service. The process design considered a structure with the following sub-processes: (1) Initialization Process, comprising a group of activities that formally initiate the service, such as receipt of transport requests, opening of necessary service management documentation and initial analysis of transport request; (2) Key Processes, comprising the main steps in IECTM (planning, scheduling and performance evaluation); (3) Supporting Processes, comprising sub-processes not directly linked to management (preliminary feasibility study, cost estimate, technical monitoring of transport, contracting and billing and payment), but necessary to address service constraints; and (4) Finalization Process, comprising a number of activities that formally close the service, such as closure of service management documentation, customer satisfaction analyses, overall service evaluation and filing of process.

Characterization of the IECTM macro-process reflects the order cycle analysis, which identified general order processing flows, in turn allowing sub-processes to be ordered in

Pesquisa Operacional, v.30, n.2, p.305-330, Maio a Agosto de 2010 
terms of the priority of the information necessary for their execution. Figure 6 (below) shows the IECTM macro-process, the sub-processes and flows of which are arranged according to the order cycle necessary to execute the service.

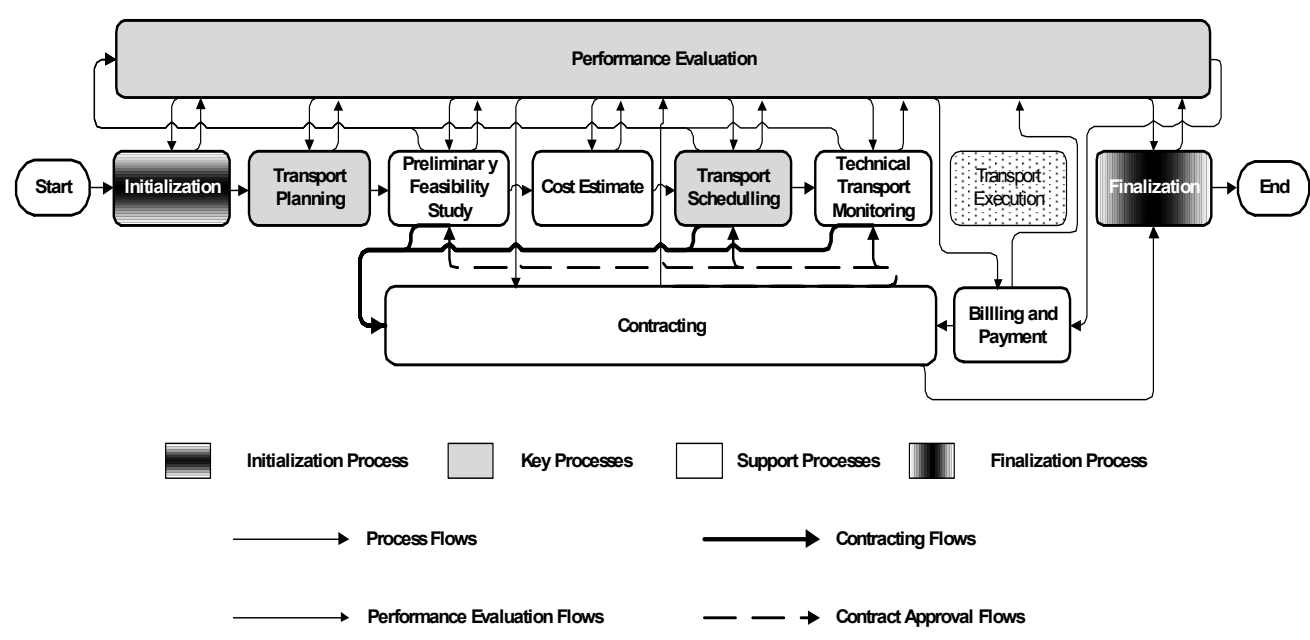

Figure 6 - Sub-processes of a generic electric sector IECTM process.

As shown, there are three key sub-processes in IECTM: transport planning, transport scheduling and performance evaluation. Transport planning submits an initial plan or proposal of intentions. The goal is to define "what" activities make up the operation and "how" they are to be executed. This sub-process considers aspects of the route (road capacity etc.), the cargo (dimensions and weight), the alternative modes of transport, origin and destination (access and loading/unloading structures and accesses), legal restrictions (legislation), organizations involved, equipment limitations (capacity, maneuverability etc.) and so on. Resources to be acquired and preliminary scheduling of contracted services are also defined (feasibility studies etc.).

Transport scheduling makes it possible to define the sequence and best timing (deadlines) for executing the activities proposed in the plan, given the available resources. Activities that occur before, during and after transport are taken into account, after which the time and place of execution are defined. Performance evaluation monitors, controls and directs all the activities that contribute to completion of the transport (Bowersox \& Closs, 1999). The monitoring accompanies and records chronological system performance, and maintains both clients and transport managers informed. The control continuously accompanies execution of the activities, enabling corrective action to be taken wherever values do not match the planned goals (Ballou, 2001). The directing specifies performance metrics to orient the firm's workforce to sustain the performance stipulated and achieve pre-established business targets. In this sub-process, client perception of results is taken into consideration both at the tacit/strategic level (demands met perfectly) and at the operational level (performance of IECTM activities). Note that the actual transport activity itself, despite being an important step in the service (Chart 1 - Service steps), is not a transport management activity and, therefore, has not been considered in the IECTM process. For instance, performance in the 
second sub-process (transport scheduling) is a function of the level of integration among the entities involved, which can generate constraints on both intra- and inter-firm information flows.

Among the supporting sub-processes, the Preliminary Feasibility Study includes surveying dimensional and structural aspects of the roads that make up the route. The Cost Estimate assesses the costs of the activities necessary to meet the requests, whether to carry out the transport or for internal budgeting or client quotes. The Technical Transport Monitoring supports performance evaluation by defining the resources necessary for full-time inspection of transport execution. This inspection includes verifying the safety and physical integrity conditions of the IEC, reporting events responsible for delays or damage to the IEC or to the route (Transport Technical Monitoring Report), and formalizing the information to be used to improve performance in future transport services. Contracting guides service outsourcing according to normative instructions and existing laws governing the process. Billing and Payment comprise the legal and organizational procedures necessary to contract services to be executed. Billing documents are received and analyzed, supplier data are verified, invoices are issued, balance sheets are drawn up, payment is released and contract processes are filed.

Besides formalizing the IECTM macro-process, this stage identified documentation and information that are byproducts of sub-processes or are necessary resources for subsequent processes, and defined control points for performance evaluation.

\subsubsection{Analysis of functions and attributions}

The analysis of functions and attributions detailed the flows in each sub-process by activity level, procedure and even task. This stage included a review of service specifications, work instructions, internal quality systems and methods and organization manuals.

In addition, technical personnel involved in the service were interviewed. The knowledge formalized in this stage refers to the flows of documents that identify the modus operandi and reflect the firm's operational culture. From these flows it was possible to identify business interfaces (internal and external), establish time markers and specify business relationships. Knowledge capitalized in this stage established a parallel between "how they are" and "how they should be" for IECTM sub-process activities. Chart 2 (below) shows the need for process redesign or even new processes in order to match goals (strategy) and functions and attributions of the process (operation).

Comparison between current and potential states ("how things are" and "how things should be") promotes improvements that can range from sub-process redesign and introduction of new sub-processes, through to formalization of working instructions and service specifications with more detailed information (knowledge) relating to goals (what), activities and procedures (how), task scheduling (when) and human resource allocation (who) for the service to be completed according to client needs. 
Chart 2 - Analysis of functions and attributions in IECTM.

\begin{tabular}{|c|c|c|}
\hline Functions and Attributions & Proces ses (How are) & Processes (How should be) \\
\hline Receive service request & Analys is of Request & Material Transportation Management \\
\hline Analyse request & Analys is of Request & Analys is of Request \\
\hline Plan the service & & Transportation Planning \\
\hline Estimate costs & & Cost Estimation \\
\hline Estudy route feas ibility & Technical Monitor. and Feasib. Study & Feasibility Preliminary Study \\
\hline Schedule trans portation & Imported Material Transportation & Transportation Scheduling \\
\hline Monitor trans portation & Technical Monitor. and Feasib. Study & Technical Transportation Monitoring \\
\hline Contract services & Contracting & Contracting \\
\hline Receive and Pay for services & Billing and Payment Release & Billing and Payment Release \\
\hline Finish services & Analys is of Request & Material Transportation Management \\
\hline Monitoring, Controlling and Directioning (Strategic) & Service Management & Service Management \\
\hline Monitoring, Controlling and Directioning (Tatic./Operat.) & Service Adminis tration & Service Execution Evaluation \\
\hline \multicolumn{3}{|c|}{\begin{tabular}{|c|c|} 
Improvement Indicators & \\
\end{tabular}} \\
\hline Total processes/subproces ses & 8 & 15 \\
\hline Totalnew processes/subprocesses & 0 & 7 \\
\hline Total redes igned processes/subprocess es & 0 & 8 \\
\hline Total service specifications & 1 & 1 \\
\hline Total new work instructions & 7 & 14 \\
\hline \multicolumn{3}{|l|}{ Total control points } \\
\hline Strategic & 0 & 2 \\
\hline Tatical/Operational & 0 & 9 \\
\hline
\end{tabular}

New Processes

\section{Discussion}

After concluding the S-C-E-I cycles, the following observations were made as regards the IEC transport management processes performed by the firm: redesign of the IEC transport management processes demanded concentrated effort by the whole team involved in the process, with a view to identifying possible options for improving them. From the results of the IEC transport management diagnostic process, firm personnel perceived a clear need to promote redesign of the processes that make up this service. All steps of redesign received orientation, criticism and validation from these staff members in all the versions developed over the course of production of the new maps. After seventeen versions, the team arrived at the process (macro-process and sub-processes) designs that it was believed characterized the IEC transport service.

Support from the knowledge generation model enabled information to be captured from the organizational environment, including interlocutors and their participation in performing the transport service. This permits a more comprehensive view of the entities involved and their actual contributions, besides identifying the impacts on transport performance caused by inefficiencies in managing relationships. Flow analysis made it possible to identify the main information (needs, resources etc.), documents (requests, authorizations, taxes etc.) and services (necessary conditions, fundamental steps, types of service), reinforcing the importance of commitment by the entities involved and defining levels of intra- and inter-firm relationship, as well as the moments when such relations occur. This fosters a more realistic view of the resources and sub-products involved in IECTM in the sector under analysis.

The Process Analysis contemplated the complete redesign of the IEC transport management processes (macro- and sub-processes) and thus demanded concentrated effort by the whole team involved - both those internal and external to the firm - with a view to identifying possible options for improving them. Note that, although the emphasis of the study was 
on IEC, the macro-process design approach was broader in scope and not limited to this type of cargo alone.

Given the information detailed in the previous stages, the Analysis of Functions and Attributions provided the basis for keeping sub-processes aligned with the operational plans and identifying potential control points. In this stage, tacit knowledge externalized in process maps, service specifications and working instructions enables processes, activities and business rules to be standardized. This makes it feasible to convey knowledge to employees, as well as to perform service quality control and reduce costs and waste.

In addition, the Business Process Analysis enabled knowledge on organizational performance to be formalized and capitalized. Through IECTM macro-process design aligned with the strategic goals, such knowledge afforded employees a process perspective, offering opportunities to implement available business integration strategies and technology. In addition, decision-making became more focused on client needs and expectations.

The generation and capitalization of knowledge about IECTM leads to the formation of a knowledge base regarding transport of this type of cargo, identifying the business entities involved in each request, defining the transport service steps and kinds of information at each step, and classifying the variables considered in the service. The main results obtained by applying the proposed organizational analysis methodology were identification of discrepancies (planned vs. accomplished) and awareness of the need for continuous change and improvement.

Despite the results for the firm and for the specific department responsible for the service, exacting challenges had to be met during application of the methodology, which are largely inherent to this kind of undertaking. Prominent among the key challenges were those relating to the employees involved in performing the service, viz.: resistance to interference from persons external to the process; lack of belief in the potential for results and often, for particular reasons, lack of interest in applying the methodology; insecurity with regard to possible changes resulting from the strategic realignment, process redesign or redefinition of service functions and attributions; and weaknesses as regards process execution procedures.

Another difficulty has to do with the fact that the firm is a public enterprise and is thus subject to legislation that is quite inflexible (deadlines) and bureaucratic (documentation), particularly as regards the service procurement process, which was also considered in the IEC management. These adversities were circumvented by strategies to enlighten and build awareness among employees as regards participation by outsiders, potential results, possible changes in processes and weaknesses in procedures. In addition, total and unrestricted support from the firm's senior management was fundamental in motivating the employees and particularly in circumventing interests contrary to application of the methodology arising from employees directly or indirectly involved.

\section{Final Remarks}

Most of the business information and knowledge available in organizations, and even some of their business processes, is not to be found in (explicit) structured, documented form, making it unavailable to both veteran and new employees, and to other stakeholders. In some cases, these resources are ultimately lost within the organization. Accordingly, the development of theoretical structures that make provision for capturing knowledge about business processes that contribute directly or indirectly to adding value to goods or services 
generated, and for sharing it among individuals and groups, is fundamental to business success (Kalpic \& Bernus, 2002).

Business process-oriented analytical approaches have been quite widely used as a tool for diagnosing and eliminating deficiencies (time overruns or profit margin losses); as a strategy for continuous system improvement (increased service opportunities); as a script for organizational redirection (operation on recently deregulated markets); and as a plan for designing new business entities. Such structures have also proven useful to executives fostering vision, leadership and drive in favor of change; to managers implementing such changes company-wide; and to analysts designing systems and procedures to enable managers to implement changes. However, for such forces to work efficiently it is necessary to foster alignment between their objectives and processes (Rummler \& Brache, 1995), so that performance of the activities pursued is suited to achieving the objectives planned.

At each step of the methodology, the KM model leads to the formalization, capitalization and transfer of the (tacit) intellectual capital present only in the mind of the most experienced employees. Acquisition of this valuable resource enables all the personnel involved to move on, from a local perspective restricted to their functions, to a broader, overall view of the business, permitting a comprehension of how each resource (employees, technologies, infrastructure etc.) participates in executing, and aggregating value to, the service. Nonetheless, as with any strategy involving KM and BPM models, the methodology has proven to be rather dependent on support from senior management, which was fundamental - through awareness-building and motivation initiatives - to overcoming resistance resulting from lack of knowledge and a disbelief among the employees involved that applying the KM methodology might offer the possibility of improving performance, given their roles in the IECTM and the relevance of their individual contribution to developing new processes or initiatives to improve existing ones.

Above all, application of the methodology proposed provided the firm with a formalized/externalized knowledge structure relating to the IEC transport management service. That structure not only offers the possibility of being transferred and absorbed (internalized), in the form of capitalized knowledge, by all those involved in this and other services performed, but it also constitutes one way of fostering and retaining knowledge about that service. In this way, part of the knowledge that used to be lost by employees' leaving (dismissals, promotions, retirements etc.) comes to be maintained in the organization and can be transferred among those who remain.

From the point of view of the senior management, the KM-supported and BPM-oriented organizational analysis methodology yielded good results, as regards forming a knowledge base capable of promoting process improvements for their IECTM problem. At each stage in application of the methodology, it was possible to generate, formalize and capitalize knowledge on aspects relating to IEC materials (definition, types, suppliers, users, importance of IEC etc.), operations (transport step, entities involved etc.) and management (key and supporting sub-processes, information and documentation flows, activities, procedures etc.) (Melo, 2006).

From the point of view of the firm employees involved, application of the methodology constituted an opportunity to: obtain a more comprehensive vision considering all the stakeholders (suppliers, regulators, partners, clients etc.) and steps (planning, scheduling and performance evaluation) that make up the service; identify information and document flows and thus internal and external business and technological interfaces involved in the service; 
identify shortcomings in service execution, by being able to compare between issues (what, when, how, who and where) in processes as they "are" executed (present state) and as they "should be" (potential state); improve business strategic alignment, because when functions and attributions are reviewed and redefined, processes can be structured to adhere more closely to attainment of goals (historical and planning) and thus to service objectives; and standardize activities, procedures and tasks by formulating/redefining process-related documentation (service specifications, work instructions etc.).

The proposed methodology also capitalized knowledge relating to a logistics model specifically directed to the electric power sector. In this model, two sub-systems were defined, which have different functions in the value aggregation process, but are integrated for the purpose of promoting efficient and effective flows of materials, services and information throughout the processes that make up the service.

Even though the results obtained in the case under consideration have to be evaluated in the light of their limitations (electric sector IECTM process), the structure of the proposed methodology can be generalized, because it refers to organizational analysis directed to making best use of knowledge and processes, which are resources typically crucial to best performance in any business.

As regards future research, investigation of quantitative indicators would make it possible to express potential improvements towards reduced cycle times and service costs, and increased client satisfaction. Such indicators would provide metrics for performance improvement initiatives based on better use of resources internal to the firm.

\section{References}

(1) Adesola, S. \& Baines, T. (2005). Developing and Evaluating a Methodology for Business Process Improvement. Business Process Management Journal, 11(1), 37-46.

(2) Aguilar-Savén, R.S. (2004). Business Process Modeling: Review and Framework. International Journal of Production Economics, 90, 129-149.

(3) Al-Mashari, M. \& Zairi, M. (1999). Managing Strategic Business Performance Improvement: An Integrative Progressive Approach. Knowledge and Process Management, 6(4), 227-237.

(4) Apostolou, D.; Mentzas, G.; Young, R. \& Abecker, A. (2000). Consolidating the Product Versus Process Approaches in Knowledge Management: The Know-Net Approach. In: <www.know-net.org/PAKeM2000.pdf>, September 10, 2000.

(5) Attaran, M.T. (2004). Exploring the Relationship between Information Technology and Business Process Reengineering. Information \& Management, 41, 585-596.

(6) Ballou, R.H. (2001). Gerenciamento da Cadeia de Suprimentos. $4^{\text {th }}$ ed., Bookman, Porto Alegre.

(7) Barthelmé, F.; Ermine, J. \& Rosenthal-Sabroux, C. (1998). An Architecture for Knowledge Evolution in Organizations. European Journal of Operational Research, 109, 414-427.

(8) Basu, A. (1998). Perspectives on Operational Research in Data and Knowledge Management. European Journal of Operational Research, 111, 1-14. 
(9) Bhatt, G.D. (2000). An Empirical Examination of the Effects of Information Systems Integration on Business Process Improvement. International Journal of Operations \& Production Management, 20(11), 1331-1359.

(10) Bhatt, G.D. \& Stump, R. (2001). An Empirical Derived Model of Role IS Networks in Business Process Improvement Initiatives. Omega, 29, 29-48.

(11) Bolloju, N.; Khalifa, M. \& Turban, E. (2002). Integrating Knowledge Management into Enterprise Environments for the Next Generation Decision Support. Decision Support Systems, 33(2), 163-176.

(12) Bowersox, D.J. \& Closs, D.J. (1999). Logística Empresarial: O Processo de Integração da Cadeia de Suprimento. Atlas, Rio de Janeiro.

(13) Cameron, N.S. \& Braiden, P.M. (2004). Using Business Process Re-engineering for the Development of Production Efficiency in Companies Making Engineered to Order Products. International Journal of Production Economics, 89, 261-263.

(14) Chan, S.L. \& Choi, C.F. (1997). A Conceptual and Analytical Framework for Business Process Reengineering. International Journal of Production Economics, 50, 211-223.

(15) Chua, A. (2004). Knowledge Management Systems Architecture: A Bridge between KM Consultants and Technologists. International Journal of Information Management, 24, 87-98.

(16) Clarke, P. \& Cooper, M. (2000). Knowledge Management and Collaboration. In: <http:// sunsite.informatik.rwth-aachen.de/Publications/CEUR-WS/Vol-34/clarke_cooper.pdf>, March 20, 2010.

(17) Cruz, T. (2003). Sistemas, Métodos \& Processos. Atlas, São Paulo.

(18) De Sordi, J.O. (2005). Gestão por Processos: Uma Abordagem da Moderna Administração. Saraiva, São Paulo.

(19) DNIT (2003). Resolução de 6 de dezembro de 2003 - Departamento Nacional de InfraEstrutura de Transportes. In: <www.dnit.gov.br>, December 6, 2003, Brazil.

(20) DNIT (2004). Resolução No. 11 - Departamento Nacional de Infra-Estrutura de Transportes. In: <www.dnit.gov.br>, October 19, 2004, Brazil.

(21) Franken, H.M.; De Weger, M.K.; Quartel, D.A.C. \& Ferreira Pires, L. (1996). On Engineering Support for Business Process Modelling and Redesign. In: $<$ http://arch.csutwente.nl/Publications/papers/bpr96.pdf>, January 8, 2005.

(22) Furnas (2010). Perfil. In: <http://www.furnas.com.br>, March 21, 2010.

(23) Grundstein, M.; Rosenthal-Sabroux, C. \& Pachulski, A. (2003). Reinforcing Decision Aid by Capitalizing on Company's Knowledge: Future Prospects. European Journal of Operational Research, 145, 256-272.

(24) Gulledge Jr., T.R. \& Sommer, R.A. (2002). Business Process Management: Public Sector Implications. Business Process Management Journal, 8(4), 364-376.

(25) Gunasekaran, A. \& Nath, B. (1997). The Role of Information Technology in Business Process Reengineering. International Journal of Production Economics, 50, 91-104.

(26) Harrington, H.J. (1991). Business Process Improvement: the Breakthrough Strategy for Total Quality, Productivity and Competitiveness. McGraw-Hill, New York, NY. 
(27) Harrington, H.J. (1993). Aperfeiçoando Processos Empresariais. Makron Books, São Paulo.

(28) Jablonski, S.; Horn, S. \& Schlundt, M. (2001). Process Oriented Knowledge Management. In: <http://sunsite.informatik.rwth-aachen.de/Publications/CEUR-WS/ Vol-37/Jablonski.pdf>, August 27, 2004.

(29) Johansson, H.J.; McHugh, P.; Pendlebury, A.J. \& Wheller, W.A. (1993). Business Process Reengineering: Breakpoint Strategies for Market Dominance. John Wiley \& Sons, England.

(30) Kalpic, B. \& Bernus, P. (2002). Business Process Modeling in Industry - The Powerful Tool in Enterprise Management. Computers in Industry, 47, 299-318.

(31) Kettinger, W.; Teng, J. \& Guha, S. (1997). Business Process Change: a Study of Methodologies, Techniques, and Tools. MIS Quarterly, 21, March, 55-80.

(32) Khan, R.M.R. (2000). Business Process Reengineering of an Air Cargo Handling Process. International Journal of Production Economics, 63, 99-108.

(33) Klein, M.M. (1994). Reengineering Methodologies and Tools. Information Systems Management, 11(2), 30-35.

(34) Liao, S. (2003). Knowledge Management Technologies and Applications - Literature Review from 1995 to 2002. Expert Systems with Applications, 25, 155-164.

(35) Lockamy III, A. \& Smith, W.I. (1997). A Strategic Alignment Approach for Effective Business Process Reengineering: Linking Strategy, Processes and Customers for Competitive Advantage. International Journal of Production Economics, 50, 141-153.

(36) MacIntosh, R. (1997). Business Process Re-engineering: New Applications for the Techniques of Production Engineering. International Journal of Production Economics, 50(1), 43-49.

(37) MacIntosh, R. (2003). BPR: Alive and Well in the Public Sector. International Journal of Operations \& Production Management, 23(3), 327-342.

(38) Melo, A.C.S. (2006). Uma Estrutura de Análise de Operações Destinada à Melhoria de Processos do Transporte de Cargas Excepcionais Indivisíveis. D.Sc.Thesis, Engenharia de Produção, COPPE/UFRJ, RJ, Brazil, 142 pp.

(39) Melo, A.C.S.; Netto, M.A.C. \& Ferreira Filho, V.J.M. (2005). O Papel do Processamento do Pedido de Transporte de Cargas Excepcionais Indivisíveis para a Logística do Setor de Energia Elétrica. In: Anais do XXV Encontro Nacional de Engenharia de Produção - ENEGEP, PUC-RS, Porto Alegre.

(40) Nonaka, I. \& Takeuchi H. (1997). Criação do Conhecimento na Empresa: Como as Empresas Japonesas Geram a Dinâmica da Inovação. Campus, Rio de Janeiro.

(41) Roy, R.; Rey, F.M.; Wegen, B. \& Steele, A. (2000). A Framework to Create Performance Indicators in Knowledge Management. In: $<$ http://sunsite.informatik.rwthaachen.de/Publications/CEUR-WS/Vol-34/roy_et_al.pdf>, August 27, 2004.

(42) Rummler, G.A. \& Brache, A.P. (1995). Improving Performance: How to Manage the White Space on the Organization Chart. ${ }^{\text {nd }}$ ed., Jossey-Bass Publishers, San Francisco. 
(43) Schoeler, S.L. (2000). A Movimentação de Cargas Pesadas em Portos Brasileiros: Dificuldades e Perspectivas. M.Sc. Dissertation, PPEP/UFSC, Florianópolis, SC, Brazil.

(44) Schulze, A. (2001). Applied Knowledge Management in Innovation Processes. In: $<$ http://sunsite.informatik.rwth-aachen.de/Publications/CEUR-WS/Vol-37/Schulze.pdf>, September, 2004.

(45) Smart, P.A.; Childe, S.J. \& Maull, R.S. (1998). Supporting Business Process Reengineering in Industry: Towards a Methodology. In: Process Engineering: Advancing the State-of-the-Art [edited by R. Gulladge and J. Elzinga], Kluwer Academic, Boston, MA, 283-319.

(46) Spiegler, I. (2003). Technology and Knowledge: Bridging a "Generating" Gap. Information \& Management, 40, 533-539.

(47) Stadelmann, M. (2000). Shareholder Value through Knowledge Management How IT-based Knowledge Management Generates the Conditions for Creating and Retaining Value. In: < http://sunsite.informatik.rwth-aachen.de/Publications/CEURWS/Vol-34/stadelmann.pdf>, September 3, 2004.

(48) Valiris, G. \& Glykas, M. (2004). Business Analysis Metrics for Business Process Redesign. Business Process Management Journal, 10, 4, 445-480.

(49) Villela, C.S.S. (2000). Mapeamento de Processos como Ferramenta de Reestruturação e Aprendizado Organizacional. M.Sc. Thesis, Engenharia de Produção, PPEP/UFSC, SC, Brasil.

(50) Wang, S. \& Ariguzo, G. (2004). Knowledge Management through the Development of Information Schema. Information \& Management, 41, 445-456.

(51) Weicher, M.; Chu, W.W.; Lin, W.C.; Le, V. \& Yu, D. (2005). Business Process Reengineering: Analysis and Recommendations. In: $<$ http://www.netlib.com/bpr1.shtml>, January 15, 2005.

(52) Yeung, C. \& Holden, T. (2000). Knowledge Re-use as Engineering Re-use: Extracting Values from Knowledge Management. In: <http://sunsite.informatik.rwthaachen.de/Publications/CEUR-WS/Vol-34/yeung_holden.pdf>, August 27, 2004.

(53) Zack, M.H. \& Serino, M. (1998). Knowledge Management and Collaboration Technologies. In: <www.lotus.com/solutions>, March 29, 2003. 